\title{
Factors Associated with Overweight and Obesity in Adolescents in Kartasura, Central Java
}

\author{
Sayida Royatun Niswah'), RB Soemanto'), Bhisma Murti1) \\ 1) Masters Program in Public Health, Sebelas Maret University \\ 2) Faculty of Social and Political Sciences, Sebelas Maret University
}

\begin{abstract}
Background: Adolescents experience rapid growth. Therefore, they are at risk to have malnutritional problems such as overweight and obesity. The Indonesian Basic Health Research in 2013 showed that the prevalence of overweight among adolescents aged 13-15 years old in Indonesia was $10.8 \%$, consisting of $8.3 \%$ overweight and $2.5 \%$ obese or very obese. The prevalence of overweight and obesity in adolescents aged 15 years and over was $18.4 \%$ in Central Java, and $10.7 \%$ in Surakarta. Overweight and obesity are important public health problems because they are known as risk factors of various chronic diseases. This study aimed to determine the factors associated with overweight and obesity in adolescents using Health Belief Model.

Subjects and Method: This was an analytic observational study with cross-sectional design. The study was conducted at Islamic Boarding School (Pondok Pesantren Modern Islam) Assalaam Kartasura, Central Java, from March to May 2017. A total sampel of 120 adolesents aged 12 to 18 years old were selected for this study using fixed disease sampling, including 30 adolescents with overweight or obesity and 90 adolescents with normal weight. The exogenous variables were perceived threat, perceived benefit, perceived barrier, self efficacy, and maternal education. The endogenous variables were physical activity, dietary pattern, and overweight or obesity. Data on dietary pattern were collected by dietary questionnnaire. The other data were collected using a set of questionnaire. Path analysis was used to analyze the association between variables involving mediating variables.
\end{abstract}

Results: Overweight or obesity was directly and negatively associated with perceived threat $(b=-$ $0.14, \mathrm{SE}=0.04, \mathrm{p}<0.001)$, perceived benefit $(\mathrm{b}=-0.10, \mathrm{SE}=0.02, \mathrm{p}<0.001)$, physical activity $(\mathrm{b}=-$ $0.24, \mathrm{SE}=0.10, \mathrm{p}=0.016)$, and dietary pattern $(\mathrm{b}=-0.33, \mathrm{SE}=0.08, \mathrm{p}<0.001)$. Overweight or obesity was directly and positively associated with perceived barrier $(b=0.13, \mathrm{SE}=0.07, \mathrm{p}=0.051)$. Dietary pattern was affected by perceived barrier $(b=-0.22 ; \mathrm{SE}=0.007 ; \mathrm{p}=0.002)$, perceived benefit $(b=0.10 ; S E=0.002 ; p<0.001)$, perceived threat $(b=0.09 ; S E=0.04 ; p=0.023)$, self effication $(b=0.22 ; \mathrm{SE}=0.09 ; \mathrm{p}=0.015)$, and maternal education $(\mathrm{b}=1.05 ; \mathrm{SE}=0.41 ; \mathrm{p}=0.010)$. Physical activity was affected by perceived benefit $(b=0.05 ; \mathrm{SE}=0.001 ; \mathrm{p}=0.002)$, perceived barrier $(b=-0.16 ; \mathrm{SE}=0.05 ; \mathrm{p}=0.002)$, perceived threat $(\mathrm{b}=0.14 ; \mathrm{SE}=0.03 ; \mathrm{p}<0.001)$, self efficacy $(b=0.24 ; \mathrm{SE}=0.06 ; \mathrm{p}<0.001)$, and maternal education $(\mathrm{b}=0.86 ; \mathrm{SE}=0.30 ; \mathrm{p}=0.005)$.

Conclusion: Overweight or obesity is negatively associated with perceived threat, perceived benefit, physical activity, and dietary pattern. Overweight or obesity is positively associated with perceived barrier. Health Belief Model can be used to explain factors associated with overweight or obesity.

Keywords: overweight, obesity, Health Belief Model

Correspondence:

Sayida Royatun Niswah. Masters Program in Public Health, Sebelas Maret University, Jl. Ir. Sutami 36 A, Surakarta 57126, Central Java. Email: cestrowsha@gmail.com. Mobile: +6285700189910 .

\section{BACKGROUND}

$\overline{\text { Health development is an effort conducted }}$ by all components of Indonesia as an nation in order to improve awareness, will, and ability of healthy life for every person to accomplish public general health status which 
is optimal, as the investment for human resource development which is socialy and economically productive. One of the indicators for health is nutritional balance that is accomplished from ideal weight (Kemenkes, 2015).

Nowadays overweight has been a problem in health. In 2014 there were 1.9 billion people suffer from overweight and most of the population had higher risk for death compare with those who did not suffer from overweight (WHO, 2016).

Adolescence is the transitional stage from childhood to adulthood. Adolescents have growth spurt, therefore various nutritional problems more often happen during this stage (Sartika, 2011).

According to National Health and Nutrition Examination Survey 2009-2010 in America, body weight percentage is categorized based on age group, namely age 2-5 years old was $26.7 \%$, age 6-11 years old was $32.6 \%$, age $12-19$ years old was $33.6 \%$. It indicates that the highest prevalence of overweight is on adolescents aged 12-19 years old or teenagers. In 2009-2010, Asia had more prevalence of overweight that was $26.4 \%$ on boys and $16.8 \%$ on girls (NOO, 2011 in Sundari 2016).

The data of Basic Health Research 2013 showed that prevalence of overweight which was more nationally on adolescents aged 13-15 years old, in Indonesia was $10.8 \%$, consisting of $8.3 \%$ overweight and $2.5 \%$ obese. Prevalence of overweight on adolescents aged 16-18 was increasing significantly from $1.4 \%$ in 2007 to $7.3 \%$ in 2013. Incidence of overweight in Central Java on adolescents aged 15 years above reached $18.4 \%$, whereas the incidence of overweight in Surakarta was 10.7\%. The numbers above showed that the developing trend among public nowadays is overnourishment, although malnourishment is also still numerous (Kemenkes, 2013).
The result of International Agency for Obesity or commonly known as International Task Force (ITF), a WHO agency that cope with overweight children, stated that $80 \%$ children with overweight is influenced more by environmental factor, whereas the $20 \%$ remainder is influenced by genetic factor. Environmental factors are unhealthy dietary pattern and life style (Trijayanti et al., 2013).

Overweight is a risk factor for the occurrence of cardiovascular diseases and contributing on the emergence of the other diseases such hypertension, Diabetes Mellitus, kidney stone, and others. Children who are overweight during childhood will be at hight risk for overweight at adulthood. Adolescents who suffer from overweight are at risk as much as $70 \%$ to suffer from overweight at adulthood (Soegih dan Wiramihardja, 2009).

Children who are overweight are also at high risk for asthma and sleep apnea (a sleeping disorder in which breathing repeatedly stops during sleeping). Children Overweight children are often more vulnerable to musculoskeletal problems. One of the musculoskeletal problems is flat feet which caused by the loss of the medial longitudinal arch of the foot that makes the angle underneath the foot small or known as pes planus. The condition may cause pain on foot, calf, and knee while the child is walking as well as running in a quite long period of time. The most important consequence of the musculoskeletal is the child is gettier lazier to do physical activity and it aggravates the overweight condition of the child (American Academy of Pediatrics Comitte on Nutrition, 2016).

The psychological impact of overweight children is reduced confidence, susceptible to bullying, even potentially depressed. Overweight children are likely to be bullied by their friends or their environ- 
ment. It is likely to generate negative self image, low self confidence, feel different, not able to compete because of physical constraints, and other psychological problems. Overweight children are likely to be less energetic, easy to get tired, and drowsy (Sutjijoso, 2009).

The study refers to Health Belief Model (HBM). HBM theory is one of the theories of health behavior change and psychological model used to predict health behavior by focusing on individual perception and believe toward a certain disease (Priyoto, 2014; Sulaeman, 2016). The theory is articulated into 5 thinking aspects within individual that influence the individual effort to determine what good for themselves, those are perceived susceptibility, perceived severity, perceived benefit, perceived barrier, sues to action and self efficacy.

\section{SUBJECTS AND METHOD}

\section{Design of the Study}

The study used analytic observational design with cross sectional approach. The study was conducted during March - May 2017 in Islamic Boarding School Pondok Pesantren Modern Islam (PPMI) Assalaam Kartasura.

\section{Population and Sample}

The target population was 7,643 adolescents aged 12-18 years old in Kartasura. The source population was students of PPMI Assalaam who aged 12-18 years old with the total number was 1,112 students (equal to Madrasah Tsanawiyah/ Secondary School and Madrasah Aliyah/ High School).

The size of the sample of the study was in line with multivariate analysis used. For the sample size the study used a formula by Hair et al., in Murti (2013) that was $n=15^{-20}$ subjects per independent variables. There were five independent variables (exogenous) used in the study therefore the sample size used was 75-100 subjects of the study.

The sample size of the study was 120 adolescents with the ratio 1:3 consisting of 30 overweight adolescents (case group) and 90 adolescents with normal weight (control group).

\section{Variables of the Study}

There were eight variables in the study including five exogenous variables and three endogenous variables. The exogenous variables were perceived threat, perceived barrier, perceived benefit, self efficacy, maternal education. The endogenous variables were physical activity, healthy dietary pattern, and overweight

\section{Operational Definitions}

Operational definition of perceived threat variable consisting of perceived susceptibility and severity, that was the belief of an adolescent that he/she was at risk to suffer from overweight and can be serious. Perceived benefit was perception that was related to benefits to be felt if an adolescent adopted the suggested behavior.

Perceived barrier was perception related to barriers experienced if an adolescent adopted the suggested behavior. Self efficacy was the belief in one's ability to do something. Maternal education was the last education taken by mothers and its relation with maternal method in giving positive direction and advice on health behavior to avoid the incidence of overweight on adolescents. Physical activity was every body movement that produced by skeletal muscle that need energy spending.

Healthy dietary pattern was food control that considered nutrients content intake and in the study also including healthy snack pattern. Overweight was a condition in which the ratio of body weight and body height was beyond the determined standard. The standard for body weight is likely 
Journal of Health Promotion and Behavior (2017), 2(3): 207-217

https://doi.org/thejhpb.2016.02.03.02

to be determined by using BMI (Body Mass Index).

\section{Instruments of the Study}

Data collection was conducted by using questionnaires. Variables measured in the study were perceived threat, perceived benefit, perceived barrier, self efficacy, maternal education, physical activity, healthy dietary pattern, and body weight (BMI).

Reliability aspect to be tested was internal consistency represented by item-total correlation and split-half reliability repressented by Alpha Cronbach. The result of reliability test conducted were $\mathrm{r}$ counting $\geq 0.20$, as well as Alpha Cronbach $\geq 0.60$, thus all question items were stated as reliable. The test result of questionnaire reliability could be seen in Table 1 .

\section{Data Analysis}

Univariate analysis was conducted to present data characteristics of the study subjects and description of the study variables. Bivariate analysis aimed to analyze the effect of independent variables toward dependent variables by using Chi-Square test.

Multivariate analysis used path analysis to recognize direct and indirect effects between exogenous variables toward endogenous variables by means of intervening variable. The steps of path analysis among others were model specification, model identification, model fit, estimation and model re-specification.

Table 1. Result of Reliability test

\begin{tabular}{lcc}
\hline \multicolumn{1}{c}{ Variables } & Item Total Correlation & Alpha Cronbach \\
\hline Perceived Threat & $\geq 0.40$ & 0.68 \\
Perceived Barrier & $\geq 0.53$ & 0.80 \\
Perceived Benefit & $\geq 0.61$ & 0.79 \\
Self Efficacy & $\geq 0.57$ & 0.76 \\
Maternal Education & $\geq 0.52$ & 0.68 \\
Dietary Pattern & $\geq 0.74$ & 0.88 \\
Physical Activity & $\geq 0.54$ & 0.71 \\
\hline
\end{tabular}

\section{RESULT}

Characteristics of the study subjects could be seen in Table 2, in which the percentage of the study subjects was equal between male and female subjects. Respectively in female and male subjects there were 50\% subjects who were 12-18 years old. BMI ratio of the study subjects was 1:3 in which $25 \%$ were overweight and $75 \%$ have normal weight. Maternal educational level of study subjects ranged from Secondary School, High School, until University, the the most percentage was (68.3\%). It indicated that most of mothers of study subjects were university graduates.
The result of descriptive statistic of continuous data in form of perceived threat, perceived barrier, perceived benefit, maternal education, self efficacy, physical activity, healthy dietary pattern, and body weight (BMI) could be seen in Table 3 .

Table 4 showed that variables self efficacy, perceived threat, perceived benefit, maternal education, physical activity, and dietary pattern had association that was relatively strong, significant, and in one direction with BMI. Whereas variable perceived barrier had a relatively strong association, significant, and not in one direction with BMI. 
Table 2. Characteristics of the Study Subjects

\begin{tabular}{cccc}
\hline Characteristics & Category & Frequency & Percentage \\
\hline Sex categories & Male & 60 & 50 \\
Age (years) & Female & 60 & 50 \\
& 12 & 25 & 20,8 \\
& 13 & 48 & 40 \\
& 14 & 22 & 18.3 \\
& 15 & 7 & 5.8 \\
& 16 & 11 & 9.1 \\
& 17 & 6 & 5 \\
BMI & 18 & 1 & 0.8 \\
& Normal & 90 & 75 \\
Maternal Education & Overweight & 30 & 25 \\
& Secondary School & 10 & 8.3 \\
& High School & 28 & 23.3 \\
& University & 82 & 68.3 \\
\hline
\end{tabular}

Table 3. Univariate analysis on variables of the study

\begin{tabular}{lccccc}
\hline \multicolumn{1}{c}{ Variables } & N & Mean & SD & Min. & Max. \\
\hline Perceived Threat & 120 & 22.65 & 7.98 & 10 & 35 \\
Perceived Barrier & 120 & 11.18 & 4.18 & 4 & 20 \\
Perceived Benefit & 120 & 38.96 & 14.28 & 10 & 63 \\
Maternal Education & 120 & 2.12 & 0.79 & 1 & 3 \\
Self Efficacy & 120 & 13.26 & 3.74 & 4 & 20 \\
Physical Activity & 120 & 11.93 & 3.96 & 3 & 19 \\
Dietary Pattern & 120 & 13.02 & 4.71 & 4 & 20 \\
BMI & 120 & 21.85 & 4.06 & 13.50 & 34.70 \\
\hline
\end{tabular}

Tabel 3 showed that each variable had relatively small variation of data. Mean represented the average value, standard deviation (SD) represented the amount of data variation. Small SD indicated that the data were representative.

Table 4. Bivariate analysis on association between perceived threat, perceived barrier, perceived benefit, maternal education, self efficacy, physical activity, and dietary pattern toward BMI of adolescents

\begin{tabular}{lccc}
\hline & Variables & $\mathbf{r}$ & $\mathbf{p}$ \\
\hline Perceived Threat & -0.71 & $<0.001$ \\
Perceived Barrier & 0.63 & $<0.001$ \\
Perceived Benefit & -0.76 & $<0.001$ \\
Maternal Education & -0.51 & $<0.001$ \\
Self Efficacy & -0.61 & $<0.001$ \\
Physical Activity & -0.66 & $<0.001$ \\
Dietary Pattern & -0.78 & $<0.001$ \\
\hline
\end{tabular}

Picture 1 showed the structural model after estimation was conducted by using IBM SPSS AMOS 22, as the result it obtained values as it was represented in the figure. The indicators that showed the model fit of path analysis as it was presented in Table 5, also indicated the occurrence of goodness of fit measure that the result of fit index CMIN was as much as 2.31 with $\mathrm{p}=0.073, \mathrm{NFI}=$ 0.99, $\mathrm{CFI}=0.99, \mathrm{RMSEA}=0.10$. It meant the empirical model met the determined criteria and it was stated in accordance with empirical data. 
Journal of Health Promotion and Behavior (2017), 2(3): 207-217

https://doi.org/thejhpb.2016.02.03.02

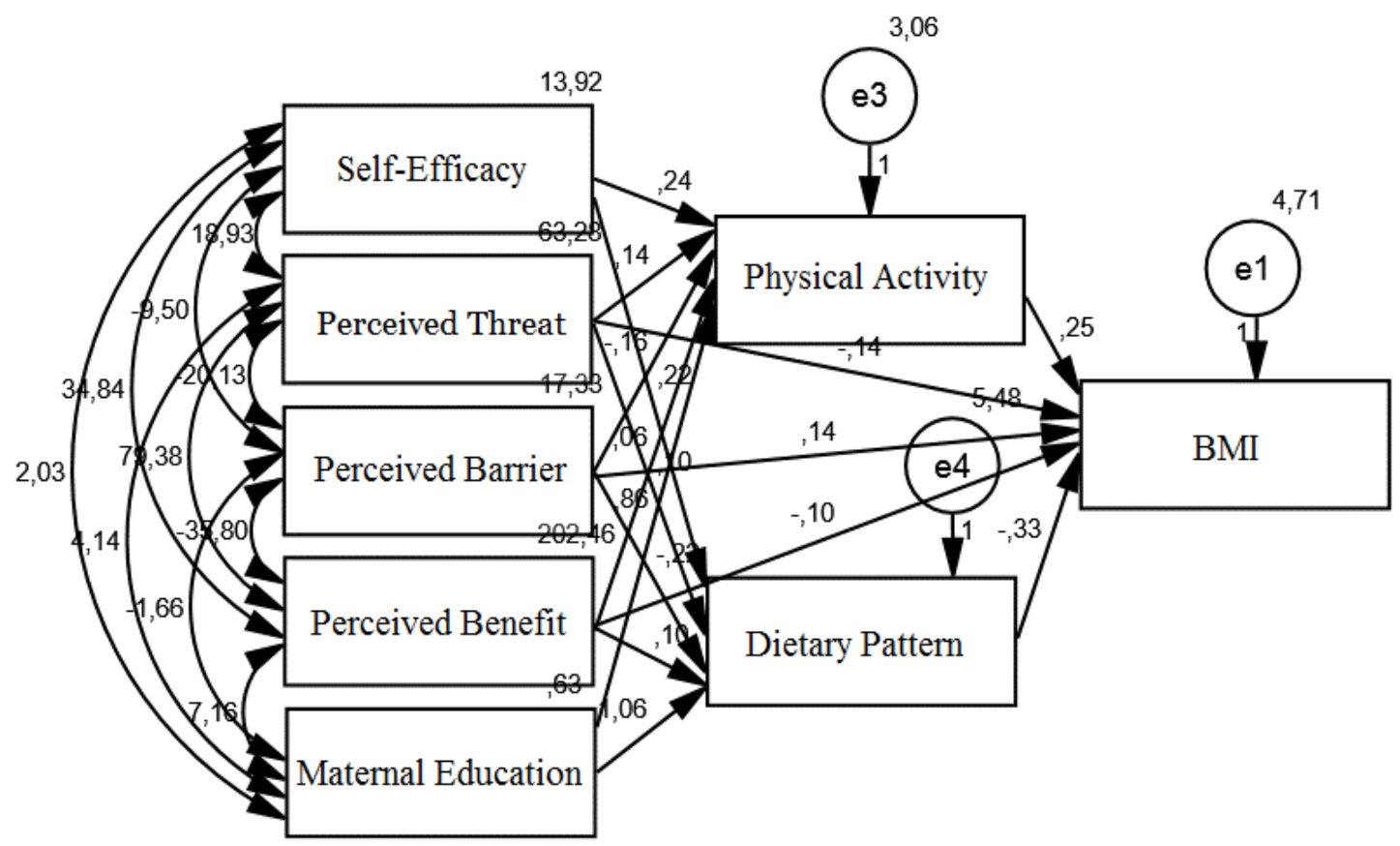

Picture 1. Structural Model of Path Analysis

Table 5. The result of path analysis

\begin{tabular}{|c|c|c|c|c|c|c|}
\hline \multicolumn{2}{|c|}{ Dependent variables } & Independent Variables & $\mathbf{b}^{*}$ & SE & $\mathbf{p}$ & $\beta^{* *}$ \\
\hline \multicolumn{7}{|c|}{ Direct Effect } \\
\hline BMI & $\leftarrow$ & Perceived Barrier & 0.13 & 0.07 & 0.051 & 0.14 \\
\hline BMI & $\leftarrow$ & Perceived Benefit & -0.10 & 0.02 & $<0.001$ & -0.36 \\
\hline BMI & $\leftarrow$ & Perceived Threat & -0.14 & 0.04 & $<0.001$ & -0.28 \\
\hline BMI & $\leftarrow$ & Physical Activity & -0.24 & 0.10 & 0.016 & -0.24 \\
\hline BMI & $\leftarrow$ & Dietary Pattern & -0.33 & 0.08 & $<0.001$ & -0.38 \\
\hline \multicolumn{7}{|l|}{ Indirect Effect } \\
\hline Dietary Pattern & $\leftarrow$ & Maternal Education & 1.05 & 0.41 & 0.010 & 0.17 \\
\hline Dietary Pattern & $\leftarrow$ & Perceived Barrier & -0.22 & 0.07 & 0.002 & -0.19 \\
\hline Dietary Pattern & $\leftarrow$ & Perceived Benefit & 0.10 & 0.02 & $<0.001$ & 0.31 \\
\hline Dietary Pattern & $\leftarrow$ & Perceived Threat & 0.09 & 0.04 & 0.023 & 0.16 \\
\hline Dietary Pattern & $\leftarrow$ & Self Efficacy & 0.22 & 0.09 & 0.015 & 0.17 \\
\hline Physical Activity & $\leftarrow$ & Self Efficacy & 0.24 & 0.06 & $<0.001$ & 0.23 \\
\hline Physical Activity & $\leftarrow$ & Perceived Barrier & -0.16 & 0.05 & 0.002 & -0.17 \\
\hline Physical Activity & $\leftarrow$ & Perceived Threat & 0.14 & 0.03 & $<0.001$ & 0.28 \\
\hline Physical Activity & $\leftarrow$ & Perceived Benefit & 0.05 & 0.01 & 0.002 & 0.19 \\
\hline Physical Activity & $\leftarrow$ & Maternal Education & 0.86 & 0.30 & 0.005 & 0.17 \\
\hline $\mathrm{N}$ Observasi $=120$ & & \multicolumn{5}{|l|}{$\mathrm{CFI}=0.99$} \\
\hline Model Fit & & \multirow{4}{*}{\multicolumn{5}{|c|}{$\begin{array}{l}\text { RMSEA }=0.10 \\
b^{*}=\text { unstandardized path coefficient } \\
\beta^{* *}=\text { standardized coefficient }\end{array}$}} \\
\hline $\mathrm{CMIN}=2.31$ & & & & & & \\
\hline$=0.073$ & & & & & & \\
\hline$=0.99$ & & & & & & \\
\hline
\end{tabular}

Table 5 showed that BMI was directly affected by perceived barrier, perceived benefit, perceived threat, physical activity, and dietary pattern.
Every one unit increase on perceived barrier would increase BMI by 0.13 unit $(b=$ $0.13, \mathrm{SE}=0.07, \mathrm{p}=0.051$ ). 
Every one unit increase on perceived benefit would reduce BMI by 0.10 unit $(b=$ $-0.10, \mathrm{SE}=0.02, \mathrm{p}<0.001$ ).

Every one unit increase on perceived threat would reduce BMI by 0.14 unit $(\mathrm{b}=$ $0.14, \mathrm{SE}=0.04, \mathrm{p}<0.001$ ).

Every one unit increase on physical activity would reduce BMI 0.24 unit $(b=-$ 0.24, $\mathrm{SE}=0.10, \mathrm{p}=0.016$ ).

Every one unit increase on healthy dietary pattern would reduce BMI 0.33 unit $(b=-0.33, S E=0.08, p<0.001)$.

Dietary pattern was affected by maternal education. Every one unit increase on maternal education would increase healthy dietary pattern by 1.05 unit $(b=1.05, S E=0.41, p=0.010)$.

Dietary pattern was affected by perceived barrier. Every one unit increase on perceived barrier would reduce healthy dietary pattern by 0.22 unit $(b=-0.22, \mathrm{SE}=$ 0.07, $\mathrm{p}=0.002$ ).

Dietary pattern was affected by perceived benefit. Every one unit increase on perceived benefit would increase healthy dietary pattern by 0.10 unit $(b=0.10, \mathrm{SE}=$ $0.02, \mathrm{p}<0.001)$.

Dietary pattern was affected by perceived threat. Every one unit increase on perceived threat would increase healthy dietary pattern by 0.09 unit $(b=0.09, \mathrm{SE}=$ 0.04, $\mathrm{p}=0.023$ ).

Dietary pattern was affected by self efficacy. Every one unit increase on self efficacy would increase healthy dietary pattern by 0.22 unit $(b=0.22, S E=0.09, p=0.015)$.

Physical activity was affected by self efficacy. Every one unit increase on self efficacy would increase physical activity by 0.24 unit $(b=0.24, \mathrm{SE}=0.06, \mathrm{p}<0.001)$.

Physical activity was affected by perceived barrier. Every one unit increase on perceived barrier would reduce physical activity by -0.16 unit $(b=-0.16, \mathrm{SE}=0.05$, $\mathrm{p}=0.002$ ).
Physical activity was affected by perceived threat. Every one unit increase on perceived threat would increase physical activity by 0.14 unit $(\mathrm{b}=0.14, \mathrm{SE}=0.03, \mathrm{p}<$ 0.001).

Physical activity was affected by perceived benefit. Every one unit increase on perceived benefit would increase physical activity by 0.05 unit $(b=0.05, \mathrm{SE}=0.01, \mathrm{p}=$ 0.002).

A Physical activity was affected by maternal education. Every one unit increase on maternal education would increase physical activity by 0.22 unit $(\mathrm{b}=$ $0.86, \mathrm{SE}=0.30, \mathrm{p}=0.005$ ).

\section{DISCUSSION}

\section{The effect of perceived barrier toward overweight on adolescents}

Perceived barrier is the barrier within the person to conduct health behavior. The association between perceived barrier and health behavior was negative. If the association between perceived barrier and health behavior was high, then health behavior would not be conducted (Priyoto, 2014; Sulaeman, 2016).

The result of the study showed that there was a direct positive effect of perceived barrier toward adolescents' body weight, as well as an indirect positive effect, by means of variable physical activity and healthy dietary pattern, which was statistically significant. It indicated that the more adolescents experienced the extensive barrier in conducting health behavior, hence the possibility to successfully conduct the behavior was getting smaller. The encountered barrier is a potential negative consequence that may appear when taking certain action including physical, psychological, and financial demand in accordance with HBM theory that was developed byRosenstock (1994). 
Some adolescents believe that parents or family members easily to gain weight. It is included into perceived barrier and supports a theory by Proverawati (2010) also Guyton and Hall (2010) that family does not only share gen, but also life style. Adolescents who come from overweight family also, are likely to be at risk to overweight, in particular it is related to the availability of high calorie food and physical activity which is neglected (Sajawandi, 2015). It is in line with a theory by Indra (2006) and Mukhtiharti (2010) that reveal that body weight is closely related to genetic factor.

Sarwono (2010) mentions adolescent stages of development, namely early adolescence, middle adolescence, late adolescence. Middle adolescents have particular characteristics, namely making a lot of interactions and really need the company of friends. They are pleased if acknowledged by a lot of friends. Having a tendency to be narcissistic, they love themselves and are fond of friends who are similar to them. The characteristics are beneficial if they get along with peer friends who have healthy behavior. On the contrary, it becomes a barrier when they get along with friends with unhealthy behavior. Since it is awfully likely they get affected to behave unhealthily.

\section{The effect of perceived benefits toward overweight on adolescents}

Perceived benefit is related to benefits experienced by a person if the person adopts the suggested behavior, including considering the advantages gained between the expenses and the level of illness (Sulaeman, 2016).

The result showed that perceived benefit give negative both direct effect as well as indirect toward overweight on adolescents. Adolescents who feel the benefits of ideal weight, such as feeling more confidence, getting along easily, doing activities energetically, and are not vulnerable to bullying, are likely to perform health behavior in the form of physical activity and good dietary pattern. Adolescents who have strong perceived benefit are more aware to conduct things that can evade themselves from overweight.

\section{The effect of perceived threat towa- rd overweight on adolescents}

Perceived threat includes perceived susceptibility and perceived severity. The bigger risk sensed by a person toward a certain disease is, the bigger possibility to be involved into behavior that reduces the risk. In other words, the higher perceived threat is, the bigger motivation to perform health behavior (Sulaeman, 2016).

The result of path analysis showed that there was an association both direct and indirect between perceived threat and overweight on adolescents. Adolescents who have high perception about the threat of overweight, feel gaining weight easily, or feel difficult to lose weight, are likely to do physical activity regularly and implement healthy dietary pattern.

\section{The effect of physical activity toward overweight on adolescents}

Sajawandi (2015) mentions that one of factors that affect body weight is physical activity. A person who is less active or does not perform balanced physical activity is likely to be overweight (Budiyati, 2011; Maidelwita, 2012).

The result of the study showed that physical activity gave direct negative effect toward overweight on adolescents. Adolescents who performed less physical activity were potentially overweight (high BMI). The effort to perform physical activity was also affected by perceived threat, perceived barrier, perceived benefit, self efficacy, and maternal education. The variables that gave 
the biggest effect were self efficacy and maternal education.

Adolescents need physical activity since it is beneficial for optimal growth. The benefits of physical activity for adolescent among others are keeping muscles and joints healthy, improving mood, reducing anxiety, stress, and depression (factors that contribute on weight gain), improve sleeping quality, reduce the risk for heart diseases, stroke, high blood pressure, and diabetes, improve blood circulation, improve the function of vital organs such as heart and lungs, and reducing the risk for cancer as the result of overweight (Nurmalina, 2011).

\section{The effect of healthy dietary} pattern toward overweight on adolescents

Another factor that affects body weight is dietary pattern. A person that often consume high fat food is likely to suffer overweight (Budiyati, 2011; Maidelwita, 2012).

Several causes of dietary pattern that affect overweight are in relation to what commonly to consume and how often to consume (Sajawandi, 2015).

The result of path analysis showed that healthy dietary pattern had direct negative effect toward overweight on adolescents. Adolescents with healthy dietary pattern are likely to have normal BMI, meanwhile adolescents with less healthy dietary pattern are likely to have more BMI (overweight).

\section{The effect of maternal education toward overweight on adolescents}

The result of path analysis showed that maternal education greatly and significantly affected healthy dietary pattern. The result of the study is in accordance with a theory by Suhardjo (2007) that educational level affects the behavior change and healthy lifestyle.
Higher educational level will facilitate a person or a community to understand information and implement it in daily life, especially in term of health. Formal education shapes one's values in particular in receiving new things.

Maternal education is related to mothers' method in infusing values about the importance of healthy lifestyle to adolescents, such as having physical activity and practicing healthy dietary pattern.

\section{The effect of Self efficacy toward overweight on adolescents}

Self efficacy refers to individual perception about competency to successfully perform a behavior. If a person believes that a new behavior is beneficial (perceived benefit) however the person thinks not able to do it, then the person will not perform the behavior. Yet only by believing that he/she is able to do something beneficial for him/herself (self efficacy), the person is actually able to do so (Priyoto, 2014; Sulaeman, 2016).

The result of path analysis showed that self efficacy greatly and significantly affected physical activity and healthy dietary pattern on adolescents. It is in accordance with a theory of Bandura in Feist and Feist (2010) that self efficacy greatly affects one's behavior as a motivation to be more enthusiastic to perform activity.

\section{REFERENCE}

$\overline{\text { American Academy of Pediatrics Comitte }}$ on Nutrition (2016). Chilhood Obesity. Accessed from: https://ihcw.aap.org/Documents/POPOT/PDFs/obesity_issuebrief20o8.pdf. Diakses 27 Februari 2017.

Budiyati (2011). Analisis Faktor Penyebab Obesitas pada Anak Usia Sekolah di SD Islam Al-Azhar 14 Kota Semarang. 
Tesis Univeristas Indonesia Jakarta: unpublished.

Feist J, Feist (2010). Theories of Personality. Yogyakarta: Pustaka Pelajar.

Guyton, Hall (2007). Bahan Ajar Fisiologi Kedokteran. Jakarta: EGC.

Indra MR (2006). Dasar Genetik Obesitas Viseral. Jurnal Kedokteran Brawijaya. 22(1).

Kementerian Kesehatan RI (2013). Riset Kesehatan Dasar; RISKESDAS. Jakarta: Balitbang Kemenkes RI.

(2015). Rencana Strategis Kementerian Kesehatan Tahun 2015-2019.

Kuniasih (2010). Sehat dan Bugar Berkat Gizi Seimbang. Jakarta: Gramedia.

Maidelwita Y (2012). Pengaruh Faktor Genetik, Pola Konsumsi, dan Aktivitas Fisik dengan Kejadian Obesitas pada Anak Kelas 4-6 SBI Percobaan Ujung Gurun Padang. KTI STIKes MERCUBAKTIJAYA, Padang.

Mukhtiharti (2010). Faktor Risiko Kejadian Obesitas pada Remaja SMAN 2 dan 3 di Kota Pekalongan Tahun 2010. Tugas Akhir Universitas Pekalongan: Unpublished

Murti B (2013). Desain dan Ukuran Sampel untuk Penelitian Kuantitatif dan Kualitatif di Bidang Kesehatan.

Nurmalina R (2011). Pencegahan dan Manajemen Obesitas. Bandung: Elex Media Komputindo.

Priyoto (2014). Teori Sikap dan Perilaku dalam Kesehatan. Yogyakarta: Nuha Medika.

Proverawati A (2010). Obesitas dan Gangguan Perilaku Makan pada Remaja. Yogyakarta: Nuha Medika.

Rosenstock I, Strecher V, Becker M (1994). The Health Belief Model and HIV risk behavior change. In R.J. DiClemente, and J.L. Peterson (Eds.), Preventing
AIDS: Theories and Methods of Behavioral Interventions. New York: Plenum Press.

Sajawandi L (2015). Pengaruh Obesitas pada Perkembangan Siswa Sekolah Dasar dan Penanganannya dari Pihak Sekolah dan Keluarga. Jurnal Pendidikan Sekolah Dasar, 1(2).

Sartika R (2011). Faktor Risiko Obesitas pada Anak 5-15 Tahun di Indonesia. Makara Kesehatan, 15(1): 37-43.

Sarwono P (2010). Ilmu Kebidanan. Jakarta: Yayasan Bina Pustaka.

Soegih, Wiramihardja (2009). Obesitas; Permasalaan dan Terapi Praktis. Jakarta: Sagung Seto.

Sulaeman ES (2016). Pembelajaran Model dan Teori Perilaku Kesehatan; Konsep dan Aplikasi. Surakarta: UNS Press.

Sundari D (2016). Gambaran Self Esteem (Harga Diri) Mahasiswi Usia 19-21 Tahun yang Mengalami Obesitas di Asrama Akbid Ngudi Waluyo. Karya Tulis Ilmiah STIKES Ngudi Waluyo Ungaran.

Sutjijoso AR, Miranda DZ (2009). Harga Diri dan Prestasi Belajar pada Remaja yang Obesitas. Jurnal Psikologi, 3(1).

Trijayanti, Lely M, Ida T, Fatma PSA, Hasan KF, Alvin (2013). Centong Digital Praktis dan Sehat dengan Sistem Otomatis Penimbang Berat Makanan untuk Mencegah Obesitas Dini Sebagai Pendukung Program Hidup Sehat Masyarakat Indonesia. Karya Tulis Ilmiah IPB. Accessed from http://repository.ipb.ac.id/handle/123456789/73699 pada 8 Maret 2017.

WHO (2016). Obesity and Overweight. Diakses dari http://www.who.int/mediacentre/factsheets/fs311/en/ pada 27 Februari 2017. 